\title{
Effectiveness of Innovation Leadership Styles: A Manager's Influence on Ecological Innovation in Construction Projects ${ }^{1}$
}

\author{
Bart A.G. Bossink \\ Faculty of Economics and Business Administration, Vrije Universiteit Amsterdam, The \\ Netherlands
}

Keywords Construction, innovation, leadership, management, projects

\begin{abstract}
This article presents four basic innovation leadership styles: charismatic, instrumental, strategic and interactive innovation leadership. The leadership styles and their characteristics relate to process and product innovations in construction projects. A theoretical framework - which synthesizes these relations - enables explorative research into the effects of leadership on organizational innovativeness. Four case studies, observing the same manager in four comparable projects, explore the effects of each leadership style on a construction project's innovativeness in ecological terms. On an analytical level the case study explorations indicate that a manager's consistent performance of a leadership style stimulates the project's ecological innovativeness when the manager also injects the project with ecological information, knowledge and competence. It also indicates that a manager's consistent performance of a leadership
\end{abstract}

\footnotetext{
${ }^{1}$ Paper is published as an article in the journal Construction Innovation: Bossink, B.A.G. (2004) Effectiveness of innovation leadership styles: a manager's influence on ecological innovation in construction projects. Construction Innovation, 4(4), pp. 211-228.
} 
style, without an injection of information, knowledge and competence in the project, doesn't stimulate the project's ecological innovativeness.

\section{Introduction}

Managers with a strong influence on innovation processes in organizations have substantial leadership competence (Roberts and Fusfeld, 1981; Galbraith, 1982; Barczak and Wilemon, 1989; Tatum, 1989; Nam and Tatum, 1989; 1997; McDonough and Barczak, 1991; Clark and Wheelwright, 1992; Burpitt and Bigoness, 1997; Winch, 1998; Kim et al., 1999; Norrgren and Schaller, 1999; Gann, 2000; Hauschildt and Kirchmann, 2001; Stoker et al., 2001; Jung et al., 2003; Bossink, 2004). Leadership in innovative construction projects is often seen as an important management function, based on human capabilities like: entrepreneurship, championship and strategic vision (Tatum, 1989; Nam and Tatum, 1989; 1997; Winch, 1998; Gann, 2000; Bossink, 2002c, 2004). Managers driving innovation perform distinctive leadership styles. The effects of these styles on the processes in, and the outcomes of innovative construction projects is the subject of this article. A question within this scope that needs further research is: What are the effects of certain leadership styles of managers on the processes in, and the output of innovative construction projects? (Nadler and Tushman, 1990; Nam and Tatum, 1997; Bailetti et al., 1998; Rice et al., 1998; Hauschildt and Kirchmann, 2001; Bossink, 2002a, 2002b, 2002c, 2002d, Halbesleben et al., 2003; Bossink, 2004). This article is based on a research 
project consisting of four case studies in the Dutch construction industry, and in this project the above research question is split into three subquestions:

1) Which innovation driving leadership styles can be distinguished and what are the characteristics of these styles?

2) Which innovation leadership styles can be used to manage innovative construction projects?

3) What are the effects of innovation leadership styles on the innovativeness of construction projects?

The article is in six sections. This first section introduces the central theme and the key research questions. The second section contains a review of the innovation leadership literature. The third section presents a framework consisting of four leadership styles with which innovation leadership in construction projects can be described. The literature review is the basis for this theoretical framework. The fourth section describes the results of four case studies of innovative construction projects. Each case explores the performance of a leadership style in, and the effects on an innovative ecological construction project. The theoretical framework structures the explorative description. The fifth section discusses the case study findings. Finally, the sixth section ends with the main conclusions of the research project. 


\section{Innovation leadership: a review of the literature}

The literature review addresses the first research question 'Which innovation driving leadership styles can be distinguished and what are the characteristics of these styles?' The literature distinguishes two types of innovation leadership: the transformationaltransactional leadership model in the organizational behaviour literature, and the leadership role model in the innovation management literature.

The transformational-transactional leadership model

In the organizational behaviour literature, leadership relates to:

1) the personal traits of the leader, such as: intelligence, values and physical appearance (Stogdill, 1948; Kirkpatrick and Locke, 1991; Gardner, 1995);

2) the leader's behaviour, such as: the use of power, the control of rewards and the delegation of authority (Lewin, 1939; Hemphill and Coons, 1957; Likert, 1979; Blake and Mouton, 1985);

3) the organizational situation the leader is in, such as: the structure, age and environment of the leader's organization (Fiedler, 1967; Evans, 1970; Kerr and Jermier, 1978; Hersey and Blanchard, 1982; Vroom and Jago, 1988).

Leadership is seen as one of the factors that drive subordinates' innovative activity, and in the literature this leadership type is often called transformational leadership. The transformational leadership style is additional to the so-called transactional leadership style. The transactional leadership style concentrates on the control of the activities of subordinates (Burns, 1978; Bass, 1985; 1990). 
Transformational leadership consists of three factors (Howell and Avolio, 1993; Bycio et al., 1995; Koh et al., 1995). These factors and their definitions are:

1) charismatic leadership: the leader respects and inspires subordinates;

2) individualized consideration: the leader pays attention to and supports subordinates;

3) intellectual stimulation: the leader enables subordinates to improve and refresh their understanding and creativity.

Transactional leadership consists of two basic factors (Howell and Avolio, 1993; Bycio et al., 1995; Daft, 1999). These factors and their definitions are:

1) contingent reward: the leader reinforces appropriate behaviour of subordinates;

2) management by exception: the leader corrects failures of subordinates when they occur.

Researchers who measure and determine the degree to which managers in organizations facilitate their subordinates to be innovative often use the transformational-transactional leadership model (Howell and Avolio, 1995; Eisenbach et al., 1999).

\section{The leadership role model}

The innovation management literature presents leadership as a role to be performed by managers but also by employees (Chakrabarti, 1974; Roberts and Fusfeld, 1981; Kim et al., 1999; Hauschildt and Kirchmann, 2001). It typifies and defines leadership roles such as: 
1) inventor: the leader promotes the technological know-how that is translated into innovative products and services (Chakrabarti, 1974; Maidique, 1980; Lawless and Price, 1992; Shane et al., 1994; Hauschildt and Kirchmann, 2001);

2) champion: the leader promotes the organizational adoption of innovations (Chakrabarti, 1974; Maidique, 1980; Markham et al., 1991; Hauschildt and Kirchmann, 2001);

3) entrepreneur: the leader initiates, drives and controls the innovation strategies and processes in the organization (Schumpeter, 1934; Quinn, 1979; Roberts and Fusfeld, 1981; McDonough and Leifer, 1986; Nam and Tatum, 1997);

4) gatekeeper: the leader gathers and processes information about changes in the organization and its environment (Chakrabarti, 1974; Roberts and Fusfeld, 1981; Barczak and Wilemon, 1989; Kim et al., 1999);

5) sponsor: the leader promotes innovation with his/her hierarchical position (Maidique, 1980; Roberts and Fusfeld, 1981; Hauschildt and Kirchmann, 2001).

The leadership styles of these innovation leadership roles are:

1) charismatic: the leader communicates an innovation vision, energizes others to innovate and accelerates innovation processes (Nadler and Tushman, 1990; Stoker et al., 2001);

2) instrumental: the leader structures and controls innovation processes (Nadler and Tushman, 1990; Eisenbach et al., 1999);

3) strategic: the leader uses hierarchical power in favour of organizational innovation (Harmsen et al., 2000; Waters, 2000); 
4) interactive: the leader empowers others to innovate, cooperates with them to innovate and shows them how to become innovation leaders in the organization themselves (Burpitt and Bigoness, 1997; Eisenbach et al., 1999).

Researchers who explore and describe how leading individuals contribute to the creation of innovative products, technologies, and organization structures and processes, often use this innovation leadership role model (Nadler and Tushman, 1990; Nam and Tatum, 1997; Bailetti et al., 1998; Rice et al., 1998; Hauschildt and Kirchmann, 2001).

\section{The leadership styles in the leadership role model}

The transformational-transactional leadership model in the organizational behaviour literature concentrates on the relation 'leader-subordinates'. The innovation leadership role model in the innovation management literature focuses on the relation 'leaderorganization'. The issue is which of the two models fits best with the content of the second research question: 'Which innovation leadership styles can be used to manage innovative construction projects?' This research question emphasizes the relation between innovation leadership styles and innovative construction projects. An innovative construction project is an organizational form. The innovation leadership role model stresses the relation leader-organization. Because of this, the innovation leadership styles presented in the innovation leadership role model fit best with the second research question in the research project, and are chosen to be the theoretical basis.

The third research question in the research project is: 'What are the effects of innovation leadership styles on the innovativeness of construction projects?' This question stresses the effects of the innovation leadership role model's charismatic, instrumental, strategic 
and interactive leadership styles on the innovativeness of construction projects. This relation is an important theme in the literature on innovation management and various researchers published their research results. Main findings, reported in the literature, are given in the following.

Charismatic innovation leadership Charismatic leaders communicate an innovative vision, energize others to innovate and accelerate innovation processes.

Stoker et al. (2001) investigated the relationships between leadership style, individual characteristics and outcome variables of self-managing teams. They found links between charismatic leadership and perceived team innovativeness.

More specifically, Nadler and Tushman (1990) found that a charismatic leader envisions, energizes and enables people to innovate. Charismatic leadership generates energy, creates commitment, and directs individuals towards new objectives, values or aspirations.

Howell and Higgins (1990) conclude that leaders contribute significantly to the development of new products. To a certain degree they neglect organizational boundaries and official roles, use visionary statements, and try to stimulate co-workers' contributions to renewal.

Nonaka and Kenney (1991) argue, on the basis of two case study examples, that innovation leaders function as catalysts and facilitators of the innovation process. They create a context for selecting the relevant people, help them to overcome barriers, and accelerate the realization of their vision. 
Eisenbach et al. (1999) conclude that a leader of change develops a vision that is attractive to followers, takes into consideration the underlying needs and values of the key stakeholders, and is intellectually stimulating.

Barczak and Wilemon (1989) interviewed ten leaders of successful new product development teams in the electronics industry. Their findings indicate that leaders of new product development teams also play communicator and climate-setter roles.

Instrumental innovation leadership Instrumental leaders structure and control innovation processes.

Nadler and Tushman (1990) claim that an innovative leader sometimes has to be instrumental to ensure that employees really act in a manner consistent with the new goals. The instrumental leader sets goals, establishes standards and defines roles and responsibilities. He/she creates systems and processes to measure, monitor and assess behaviour and results, and to administer corrective action.

Nadler and Tushman (1990) and Eisenbach et al., (1999) found that an innovation leader sets challenging goals, and rewards behaviours that are directed toward their fulfilment.

Also Norrgren and Schaller (1999) and Stoker et al. (2001) found a relationship between structure initiating leadership and team innovativeness.

McDonough and Leifer (1986) studied 12 new product development projects in three organizations and found that projects that were considered to be a success, had project leaders who delineated task boundaries within which the members of the project team were expected to work. 
Barczak and Wilemon's (1989) research showed that new product development team leaders act as project planners and interfacers between co-innovating departments in organizations.

Sillince (1994) investigated the role of managers in enabling innovation of production management systems and found that managers considered both individual and organizational design criteria when designing a production system. Individual design criteria they concentrate on are: participation in the design of the process, and jobs and processes that can be controlled. Organizational design criteria they emphasize are: accountability structures, and availability of relevant, accurate and specific enough information.

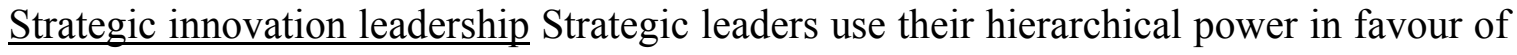
organizational innovation.

Harmsen et al. (2000) argue that strategic organizational competence, which is built over time and is based on the orientation of the company, should be known to develop strategic innovation competence. This strategic innovation competence has to fit with the organizational competence and with the past directions of the company.

Waters (2000) found that top management commitment to innovation is a basic characteristic of organizations wanting to renew their strategies and processes.

Nam and Tatum (1997) concluded, on the basis of ten studies of innovative construction projects, that leaders driving the innovation process possess a certain amount of power. Highly effective leaders have the authority for approval of key ideas. They also devote substantial time to discussion on technical matters and to detailed design. 
Also Eisenbach et al. (1999) conclude that a leader assembles and motivates a group with enough power to lead the innovative effort.

Norrgren and Schaller (1999) found that an innovation leader facilitates the development of the innovation capabilities of employees.

Saleh and Wang (1993) compared 14 innovative companies with 20 less innovative companies and found that managers of innovative companies score relatively high on the aspects 'risk taking' and 'commitment'. They strategically commit themselves to innovation, make bold decisions despite the uncertainty of their outcomes, and invest in innovation even when faced with decreasing profit margins.

Interactive innovation leadership Interactive leaders empower others to innovate, cooperate with them to innovate, and show them how to become innovation leaders themselves.

Eisenbach et al. (1999) found that an innovative leader interacts with the environment and shows individualized consideration when providing support, coaching and guidance to employees.

Nadler and Tushman (1990) state that only exceptional individuals can handle the behavioural requirements of different leadership styles. An alternative for leaders who do not combine one or more styles is to develop leadership throughout the organization. They describe leadership as a function that can be performed by multiple persons.

Rice et al. (1998) came to similar conclusions when studying the leadership function in organizations. They carried out case studies at 11 projects and collected detailed information from another 16 projects with a survey. The projects had in common that 
members were teaming up to develop radical innovations. One of the conclusions of their study is that multiple leaders are important in these projects.

Markham (1998) studied the ways innovators influenced others to support their projects in four large firms. The study indicates that innovators use cooperative tactics to influence other people and that they have a strong influence on people's target behaviour when they enjoy positive personal relationships with them.

Burpitt and Bigoness (1997) carried out a research project to investigate how specific task-related leader behaviour stimulates innovation among teams. A multimethod research project, consisting of case studies in nine organizations and surveys in 20 organizations, investigates the relationship between leader-empowering behaviour and team-level innovation. They found that empowered teams were more innovative than teams that were less empowered by their leader. Their study defined a set of supervisory behaviours that encourages team-level innovation. These behaviours include: giving the team freedom in developing problem solutions, allowing team members the opportunity to meet with clients, providing early involvement in the initial planning stages of projects, participation throughout the entire life of the project, and giving the team a major role in the overall design of a project. 


\section{Research methodology}

This section describes the basic design of the research project, presents the data collection procedures and methods that were used, and defines the theoretical framework to describe and analyse the empirical research results.

\section{Research design}

A case study-based research design addresses the third research question: 'What are the effects of innovation leadership styles on the innovativeness of construction projects?' The case study design aims to observe the charismatic, instrumental, strategic and interactive leadership styles and their effects in its actual context - an innovative construction project - and in real time, during the course of the innovative construction project. This case study approach fits with the aim of the research project to construct and apply a theoretical framework to carry out explorative research into the effects of leadership styles on the innovativeness of construction projects (Cunningham, 1997; Eisenhardt, 2002; Creswell, 2003; Yin, 2003).

Nine innovative construction projects were selected to be the subject of a case study. Comparable projects were selected to explore innovation leadership in a similar context. Each project had the ambition to be innovative in the field of ecology, was situated in the Dutch house-building sector, and was led by the same manager. This manager's leadership performance was observed and documented. From these nine cases, four cases were selected: projects in which the manager focused on one of the four leadership styles. Each project represented a different leadership style. The other five projects were hybrid 
leadership projects in which the manager performed more than one style. These projects were left aside. The selection of four comparable innovation projects, in which distinctive leadership styles were performed by the same manager, facilitated an exemplary exploration of the effects of these leadership styles on organizational innovativeness in terms of ecology.

\section{Data collection}

A research team was allowed to observe and document nine ecological building projects that were led by the same municipal manager. Each project was studied from the kick-off meeting till the final design meeting. In each project the municipal manager was interviewed on a regular basis: every two months, over a two-year period. In each project all official design meetings with the participants in the projects, that is, the rough draftmeeting(s), preliminary design-meeting(s) and the final design-meeting(s), were observed. In addition to this, in each project the rough drafts, preliminary designs and final designs were collected and analysed.

Nine projects were studied from start to finish, and afterwards, four of them were selected to be the exemplary cases. The first case is a project with the aim to design ecological civil engineering facilities in a new housing estate. In this project the municipal manager performed a charismatic leadership style. The second case is a project for the development of an environmentally friendly town and country plan. In this project the municipal manager performed an instrumental leadership style. The third case is a project with the aim to develop an ecological garden. In this project the municipal manager performed a strategic leadership style. The fourth case is a project for the design of 200 
environmentally friendly houses. In this project the municipal manager performed an interactive leadership style.

Table 1 summarizes which interviews were taken, meetings were observed, and documents were studied in the four selected cases.

Table 1. The data collection

\begin{tabular}{|c|c|}
\hline Case & Data collection \\
\hline \multirow{3}{*}{$\begin{array}{l}\text { The civil facilities project } \\
\text { with a charismatic } \\
\text { leadership style }\end{array}$} & Documents: the schedule of requirements; the final specifications and plans \\
\hline & Meetings: 3 schedules of requirement-meetings \\
\hline & Interviews: 13 interviews with the municipal manager \\
\hline \multirow{3}{*}{$\begin{array}{l}\text { The town and country } \\
\text { project with an } \\
\text { instrumental leadership } \\
\text { style }\end{array}$} & $\begin{array}{l}\text { Documents: } 2 \text { feasibility studies; the rough draft; the preliminary design; the } \\
\text { final design; the design process evaluation report }\end{array}$ \\
\hline & $\begin{array}{l}\text { Meetings: } 2 \text { rough draft-meetings; } 2 \text { preliminary design-meeting; } 2 \text { final } \\
\text { design-meetings; } 3 \text { final design-exhibitions }\end{array}$ \\
\hline & $\begin{array}{l}\text { s: } 13 \text { interviews with the municipal manager; } 2 \text { interviews with the } \\
\text { engineer }\end{array}$ \\
\hline \multirow[t]{3}{*}{$\begin{array}{l}\text { The garden project with a } \\
\text { strategic leadership style }\end{array}$} & $\begin{array}{l}\text { design, and final design for town and } \\
\text { luation report }\end{array}$ \\
\hline & $\begin{array}{l}\text { Meetings: rough draft-meeting; preliminary design-meeting; final design- } \\
\text { meeting }\end{array}$ \\
\hline & $\begin{array}{l}\text { Interviews: } 13 \text { interviews with the municipal manager; an interview with the } \\
\text { municipal designer }\end{array}$ \\
\hline \multirow{3}{*}{$\begin{array}{l}\text { The housing project with } \\
\text { an interactive leadership } \\
\text { style }\end{array}$} & ts: 7 rough drafts; 7 preliminary desig \\
\hline & $\begin{array}{l}\text { Meetings: two rough draft-meetings; } 2 \text { preliminary design-meetings; a final } \\
\text { design-meeting }\end{array}$ \\
\hline & $\begin{array}{l}\text { Interviews: } 13 \text { interviews with the municipal manager; } 7 \text { interviews with } t \\
\text { architects }\end{array}$ \\
\hline
\end{tabular}

\section{Data analysis}

A theoretical framework was constructed to explore the effects of the innovation leadership styles on the ecological innovativeness of the construction projects. The theoretical framework was based on the results of the literature review (cf. Yin, 2003). To address the relevant aspects of the third research question: 'What are the effects of innovation leadership styles on the innovativeness of construction projects?', the 
theoretical framework was based on four basic leadership styles and two indicators of organizational innovativeness.

In the theoretical framework charismatic, instrumental, strategic and interactive leadership were selected as the four main innovation leadership styles. Each innovation leadership style was divided into three characteristics. The selection criterion for the innovation leadership styles was that they had to be a main topic in most of the literature sources that were part of the literature review. The selection criterion for each characteristic was that it had to be discussed as a characteristic of the specific innovation leadership style in two or more literature sources that were part of the literature review. The innovation leadership styles and their characteristics are presented and defined in the first column of the theoretical framework presented in Table 2.

In the theoretical framework 'new processes' and 'new products' were selected as the two main indicators of the innovativeness of construction projects. The selection criterion for these indicators was that they had to be recognized as a main aspect of organizational innovativeness in most of the literature sources that were studied in the literature review. A review of international literature on ecological construction and an interview round among experts in the field of ecological construction was consulted to select the ecological characteristics of the two innovation indicators (Bossink, 2002a). Four characteristics were selected. The selection criterion for each characteristic was that it had to be a common measure of ecological innovation and had to fit with the indicators. The selected characteristics of new processes are: new ecological design practices and new ecological construction practices. The selected characteristics of new products are: new ecological designs and new ecological objects/areas (Bossink, 2002a). The indicators 
of ecological innovativeness are presented in the second column of the theoretical framework presented in Table 2 .

Table 2. The theoretical framework

\begin{tabular}{|c|c|}
\hline Innovation leadership style & $\begin{array}{l}\text { Indicator } \\
\text { ecological } \\
\text { innovation }\end{array}$ \\
\hline $\begin{array}{l}\text { Charismatic: The leader is innovation personified: } \\
\text { Communicating with vision: The leader informs employees about the innovation } \\
\text { direction (Barczak and Wilemon, 1989; Howell and Higgings, 1990; Nadler and } \\
\text { Tushman, 1990; Nonaka and Kenney, 1991; Eisenbach et al., 1999; Harmsen et al., } \\
\text { 2000; Stoker et al., 2001); } \\
\text { Energizing employees: The leader generates innovative activity in the organization } \\
\text { (Barczak and Wilemon, 1989; Howell and Higgins, 1990; Nadler and Tushman, } \\
\text { 1990; Nonaka and Kenney, 1991; Eisenbach et al., 1999; Stoker et al., 2001); } \\
\text { Accelerating innovation processes: The leader speeds up the innovative activity in } \\
\text { the organization (Barczak and Wilemon, 1989; Howell and Higgings, 1990; Nonaka } \\
\text { and Kenney, 1991; Eisenbach et al., 1999; Stoker et al., 2001). }\end{array}$ & \multirow{4}{*}{$\begin{array}{l}\text { New processes: } \\
\text { Design: new } \\
\text { ecological creation } \\
\text { activities (Bossink, } \\
2002 \mathrm{a}) \\
\quad \& \\
\text { Construction: new } \\
\text { ecological realization } \\
\text { activities (Bossink, } \\
\text { 2002a) }\end{array}$} \\
\hline $\begin{array}{l}\text { Instrumental: The leader uses management methods to create innovation structures and } \\
\text { processes in the organization: } \\
\text { - Structuring innovation processes: The leader creates organizational systems and } \\
\text { processes that produce innovative products and services (McDonough and Leifer, } \\
\text { 1986; Barczak and Wilemon, 1989; Nadler and Tushman, 1990; Sillince, 1994; Kim } \\
\text { et al., 1999; Norrgren and Schaller, 1999; Stoker et al., 2001); } \\
\text { Controlling innovation processes: The leader establishes and uses goals and } \\
\text { measures for the innovative organizational systems and processes (McDonough and } \\
\text { Leifer, 1986; Barczak and Wilemon, 1989; Nadler and Tushman, 1990; Sillince, } \\
\text { 1994; Eisenbach et al., 1999; Kim et al., 1999); } \\
\text { Rewarding innovators: The leader gratifies persons who contribute to the } \\
\text { innovative organizational systems and processes (Nadler and Tushman, 1990; } \\
\text { Sillince, 1994; Eisenbach et al., 1999). }\end{array}$ & \\
\hline $\begin{array}{l}\text { Strategic: The leader uses the hierarchical position to create innovation structures and } \\
\text { processes in the organization: } \\
\text { - Using power to innovate: The leader uses the hierarchical position to authorize } \\
\text { innovative activity and processes (Nam and Tatum, 1997; Eisenbach et al., 1999; } \\
\text { Norrgren and Schaller, 1999); } \\
\text { Committing employees to innovation: The leader assigns innovative tasks and } \\
\text { responsibilities to subordinates (Saleh and Wang, 1993; Norrgren and Schaller, } \\
\text { 1999; Waters, 2000); } \\
\text { Enabling employees to be innovative: The leader assigns innovative competences } \\
\text { to subordinates (Eisenbach et al., 1999; Norrgren and Schaller, 1999). }\end{array}$ & \\
\hline $\begin{array}{l}\text { Interactive: The leader co-innovates with other managers, employees and subordinates: } \\
\text { - Empowering innovators: The leader stimulates and allows subordinates to develop } \\
\text { and realize innovative ideas (Nadler and Tushman, 1990; Burpitt and Bigoness, } \\
\text { 1997; Kim et al., 1999); } \\
\text { Cooperating with innovative employees: The leader works together with } \\
\text { innovators to develop and realize their innovative ideas (Markham, 1998, Nadler and } \\
\text { Tushman, 1990; Eisenbach et al., 1999); } \\
\text { Developing additional leadership: The leader teaches others how to be an } \\
\text { additional innovation leader in the organization's innovative processes (Nadler and } \\
\text { Tushman, 1990, Rice et al., 1998). }\end{array}$ & \\
\hline
\end{tabular}


The research design, consisting of four comparable cases in which four distinctive innovation leadership styles are performed, and the theoretical framework, consisting of formats for leadership styles and indicators for the organizational innovativeness in ecology, facilitate the exploration of the effects of leadership styles on the ecological innovativeness of the studied construction projects. This is visualized in Figure 1.

Figure 1. Exploration of the effect of leadership styles on the ecological innovativeness of construction projects
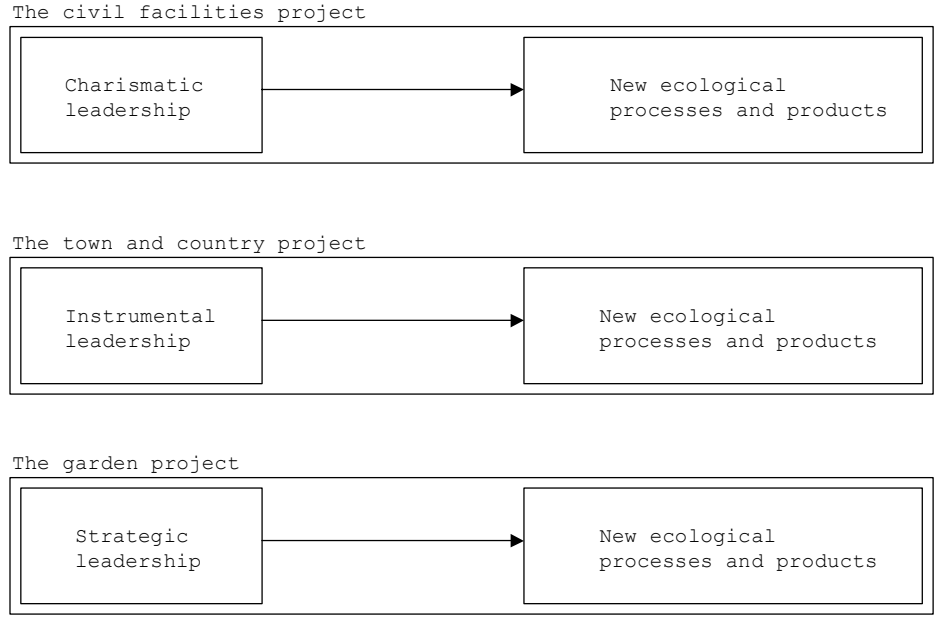

The housing project
\begin{tabular}{|l|l|}
\hline $\begin{array}{l}\text { Interactive } \\
\text { leadership }\end{array}$ & $\begin{array}{l}\text { New ecological } \\
\text { processes and products }\end{array}$ \\
\hline
\end{tabular}




\section{Effective innovation leadership: an empirical exploration}

This section presents the leadership styles the municipal manager performed in the four selected cases. Each case description starts with the innovation purpose of the project and an overview of the project's primary participants, and then focuses on the municipal manager's leadership style and the project's innovativeness. This section also contains

Table 3, a summary of the development of the municipal manager's leadership styles and the accompanying innovation results.

\section{Charismatic leadership in the civil facilities project}

In the civil facilities project the municipal manager represented the municipality in a project to design and construct various ecological civil facilities in an urban area of 250 houses. The purpose of the municipality was to develop civic facilities with environmentally friendly materials. The primary participants in this project were: a municipality as the client, represented by the municipal manager, and the same municipality as the designer, represented by a project team.

The municipal manager performed a charismatic leadership style to direct the design activities of the municipal project team and communicated in visionary images about environmental friendliness and a sustainable society. The municipal manager organized meetings to stimulate the team members to discuss ecological topics. The team members were annoyed by the so-called vague ambitions of the project and complained about the absence of concrete goals and measures. 
The municipal manager tried to energize the team members and invited them to express their visions on ecological building. The team members didn't develop any new ideas and continued complaining about fuzzy leadership.

In a last attempt to accelerate the team members' contribution to the project, the municipal manager organized meetings in which they were invited to brainstorm about the specifications of an ecological civil facilities design; with no result.

The final result of the charismatic leadership style in the civil facilities project was a completely traditional design for civic facilities without a single ecological innovation (see Table 3; first row).

\section{Instrumental leadership in the town and country project}

In the town and country project the municipal manager represented a municipality in a project to develop an ecological town and country design. The innovation purpose of the municipality was to develop a green design for an urban area of 500 houses. The primary participants in this project were: a municipality as the client, represented by the municipal manager, and an architect's firm as the designer, represented by a design team.

The municipal manager performed an instrumental leadership style and structured the processes in the project with a project plan containing the basic requirements, with planning schemes, and with a schedule of meetings.

In the first meeting the design team presented its attempts to transform the basic requirements into a detailed town and country design. The municipal manager organized many design meetings. In all meetings the design team evaluated the designs and the design processes. 
The municipal manager used a formal planning scheme to assure the quality of the design process and of the results of each design step. The design steps were documented and administrated in a project administration.

During the project, a municipal engineer who participated in the project team developed an ecological drainage system. The municipal manager integrated this contribution into the planning procedures of the town and country project.

The final result of the instrumental leadership style in the town and country project was a town and country design with many environmental innovations: the natural environment was left intact, it contained many green areas, and ecological materials were utilized (see Table 3; second row).

\section{Strategic leadership in the garden project}

In the garden project the municipal manager represented a municipality in a project to develop and design an ecological garden. The primary participants in this project were: a municipality as the client, represented by the municipal manager, and an architect's firm as the designer, represented by a managing designer. The innovation purpose of the municipality was to develop an ecological garden for an urban area of 50 houses.

The municipal manager used a strategic leadership style and hired an architect's firm to develop the ecological garden designs.

The municipal manager used client-power to direct the designer's activities. The architect had to adjust the rough draft and preliminary design according to the wishes and demands of the municipal manager. In the final ecological garden design natural elements such as 
trees, bushes, fields, and urban elements like: houses, lanes and playgrounds, were combined.

The municipal manager presented the rough draft, preliminary design and final design to a municipal designer. The municipal manager enabled the municipal designer, who was highly motivated to contribute to the design process, to develop ecological subdesigns, and arranged that they were integrated in the overall ecological garden design.

The final result of the strategic leadership style in the garden project was an ecological garden, consisting of many existing, renewed and new natural elements, in which 50 houses were situated (see Table 3; third row).

\section{Interactive leadership in the housing project}

In the housing project the municipal manager represented a municipality in a project to design 200 ecological houses. The primary participants in this project were: a municipality as the legislative body, represented by the municipal manager, and seven real estate agents as the clients, each represented by a manager.

The municipal manager used an interactive leadership style. All seven real estate agents reached an agreement with the municipal manager to design and build 10 to 50 houses each on an area owned by the municipality. They reached the agreement that after the houses were built, the real estate agents could buy the ground. The agreement enabled the real estate agents to sell their houses on the commercial market.

Part of the deal was that the real estate agents allowed the municipal manager to co-direct their housing design activities. The municipal manager requested the real estate agents to work with ecological architects, and they all agreed. 
The municipal manager acted as a shadow-client. In meetings with the real estate agents and their architects, the municipal manager convinced them to use ecological materials and to use ecological design checklists.

The municipal manager organized design workshops to evaluate the designs. All real estate agents and their architects participated and took notice of each other's results.

The municipal manager facilitated the architects to act as additional innovation leaders and they all developed housing designs with a high ecology score.

The final result of the interactive leadership style in the housing project was seven designs for 10 to 50 highly ecological houses each (see Table 3; fourth row). 
Table 3. Innovation leadership styles and indicators of organizational innovation ${ }^{2}$

\begin{tabular}{|c|c|}
\hline $\begin{array}{c}\text { Innovation } \\
\text { leadership style }\end{array}$ & $\begin{array}{c}\text { Indicator } \\
\text { ecological innovation }\end{array}$ \\
\hline $\begin{array}{l}\text { Charismatic leadership in the } \\
\text { civil facilities project: The leader } \\
\text { started to energize project members, } \\
\text { then communicated with vision, and } \\
\text { then accelerated the innovation } \\
\text { processes. }\end{array}$ & $\begin{array}{l}\text { Processes: } \\
\text { Design: a municipal innovation team was responsible for the production of an } \\
\text { ecological civil facilities design. } \\
\text { Construction: - } \\
\text { Products: } \\
\text { Designs: - } \\
\text { Objects/areas: - }\end{array}$ \\
\hline $\begin{array}{l}\text { Instrumental leadership in the } \\
\text { town and country project: The } \\
\text { leader started to control the } \\
\text { innovation processes, and then } \\
\text { structured the innovation processes. }\end{array}$ & $\begin{array}{l}\text { Processes: } \\
\text { Design: }(1) \text { an inter-organizational innovation team consisting of three designers } \\
\text { of an architect's firm, the municipal manager and a municipal engineer was } \\
\text { responsible for the production of an ecological town and country design; }(2) \text { a } \\
\text { municipal engineer was committed to the design process and generated ideas that } \\
\text { could be integrated into the ecological town and country design. } \\
\text { Construction: - } \\
\text { Products: } \\
\text { Designs: a feasible town and country design with a high ecology score. } \\
\text { Objects/areas: the town and country design was realized with minor alterations. }\end{array}$ \\
\hline $\begin{array}{l}\text { Strategic leadership in the garden } \\
\text { project: The leader started to } \\
\text { commit project members to } \\
\text { innovation, } \\
\text { then used client power to innovate, } \\
\text { and then enabled project members } \\
\text { to be innovative. }\end{array}$ & $\begin{array}{l}\text { Processes: } \\
\text { Design: (1) an inter-organizational innovation team consisting of a managing } \\
\text { designer of an architect's firm, the municipal manager and a municipal designer } \\
\text { was responsible for the production of an ecological garden design; (2) the } \\
\text { municipal designer was committed to the design process and generated ideas that } \\
\text { could be integrated into the ecological garden design. } \\
\text { Construction: - } \\
\text { Products: } \\
\text { Designs: a feasible garden design with a high ecology score. } \\
\text { Objects/areas: the garden design was realized with minor alterations. }\end{array}$ \\
\hline $\begin{array}{l}\text { Interactive leadership in the } \\
\text { housing project: The leader started } \\
\text { to cooperate with innovative project } \\
\text { members, and then developed } \\
\text { additional leadership in the } \\
\text { organization. }\end{array}$ & $\begin{array}{l}\text { Processes: } \\
\text { Design: (1) } 7 \text { inter-organizational innovation teams, each team consisting of a } \\
\text { real estate agent's manager, an architect and the municipal manager, were } \\
\text { responsible for } 10 \text { to } 50 \text { ecological housing designs each; (2) the municipal } \\
\text { manager selected architects that could act as additional innovation leaders in the } \\
\text { design projects and organized workshops in which knowledge and ideas were } \\
\text { shared. } \\
\text { Construction: } 7 \text { inter-organizational innovation teams, each team consisting of a } \\
\text { real estate agent's manager, an architect and the municipal manager, were } \\
\text { responsible for } 10 \text { to } 50 \text { ecological housing designs each. } \\
\text { Products: } \\
\text { Designs: } 7 \text { feasible designs for } 10 \text { to } 50 \text { houses each with a high ecology score. } \\
\text { Objects/areas: all designs were realized with minor alterations. }\end{array}$ \\
\hline
\end{tabular}

\footnotetext{
2 The innovation results were all officially monitored and approved as highly innovative in the field of ecology by an official body of the Dutch government. This body was responsible for the assessment and evaluation of ecological building on a national scale.
} 


\section{Discussion}

This section discusses the major findings of the case research project. It splits the findings into two parts. The first part discusses the successful innovation projects: the town and country project, the garden project, and the housing project. The second part discusses the project without innovative results: the civil facilities project. The section ends with a synthesis of the four cases' findings.

\section{Consistent leadership with an injection of information, knowledge and competence}

Three cases - the town and country project, garden project, and housing project - support the same major finding. The first part of the finding fits with the purpose of the research project to explore the effectiveness of innovation leadership styles. The second part of the finding appeared during the course of the project as a by-product. The main finding of these three cases is that (a) a manager's consistent performance of a leadership style stimulates the project's ecological innovativeness when (b) the manager also assures that it is injected with ecological information, knowledge and competence. A further description of the three cases illuminates this finding. 
Instrumental leadership in the town and country project In terms of innovative ecological project outcomes, the performance of an instrumental leadership style in the town and country project was a success. The main reasons were that the municipal manager:

- hired three designers from an external architect's firm with ecological competence;

- was assisted by a municipal engineer with relevant ecological knowledge;

- defined ecological project goals;

- selected green building methods and green design-and-material-selection checklists to realize these goals; and

- used project management methods to plan, realize and control the ecological building process.

The municipal manager based the instrumental leadership style on the conviction that this style was needed to co-ordinate the activities of the specialists in the project.

As a consequence of the presence of ecological expertise in the project and the municipal manager's efforts to plan, co-ordinate and control the contributions of the specialists, the design process delivered ecological results.

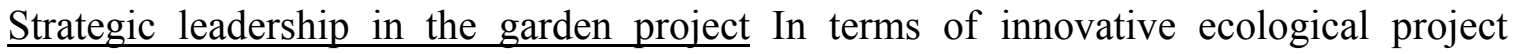
outcomes, the performance of a strategic leadership style in the garden project also was a success. The main reasons were that the municipal manager:

- hired a designer from an external consultant's firm with ecological competence;

- was assisted by a municipal designer with knowledge of ecological gardens; and 
- concentrated on directing their activities.

The municipal manager used the power, based on being the client, to commit, enable, and sometimes force them to develop innovative ideas and solutions to be integrated in the ecological garden design.

The municipal manager based the strategic leadership style on the belief that power was needed to direct the activities of various specialists in this project.

As a consequence of the presence of sufficient ecological specialists in the project and the municipal manager's directive approach the design process delivered substantial ecological results.

Interactive leadership in the housing project In terms of innovative ecological project outcomes, the performance of an interactive leadership style in the housing project also was a success. The main reasons were that the municipal manager:

- became an informal member of all project teams that were formed;

- convinced the managers of the real estate agents in all seven project teams that an ecological architect had to be hired; and

- $\quad$ supported these architects to act as additional innovation leaders in their projects.

The municipal manager based the interactive leadership style on the absence of a formal power base, and on the conviction that an interactive role could provide an informal power base.

As a consequence of the selection of ecological architects and the municipal manager's interactive leadership style the design processes delivered substantial ecological results in all seven projects. 


\section{Consistent leadership without an injection of information, knowledge and competence}

The remaining case - the civil facilities project - supports a second finding. The first part of the finding fits with the purpose of the research project to explore the effectiveness of innovation leadership styles. The second part of the finding appeared during the course of the project as a byproduct. This finding is that (a) a manager's consistent performance of a leadership style does not stimulate the project's ecological innovativeness when (b) the manager not also assures that it is injected with ecological information, knowledge and competence. A description of the civil facilities project illuminates this finding.

Charismatic leadership in the civil facilities project In terms of innovative ecological project outcomes, the performance of charismatic leadership in the civil facilities project was a failure. The main reason was that the municipal manager lacked knowledge of ecology and ecological building.

The municipal manager did not absorb information and knowledge of ecological building during the project and did not hire internal or external consultants to inject the project with the knowledge needed.

The municipal manager had to manage a project team consisting of members without competence in the field of ecology or ecological building.

The charismatic leadership style was based on the municipal manager's belief that it would inspire the participants in the project.

As a consequence of the absence of the necessary information, knowledge and competence in the project, the charismatic style had no effect. 


\section{Synthesis of the four cases' findings}

Three cases show a positive effect, and one case shows no positive effect of a consistent performance of an innovation leadership style on the ecological innovativeness of a construction project. In all four cases the presence/absence of ecological information, knowledge and competence was a crucial factor.

The construction projects studied, had an information, knowledge and competence deficiency in the field of ecology and ecological building. In the town and country project, garden project and housing project - the projects that were successful in terms of ecological innovativeness - the municipal manager eliminated this deficiency and injected the projects with ecological information, knowledge and competence. In the civil facilities project - the project that failed in terms of ecological innovativeness - the municipal manager didn't eliminate this deficiency.

On an analytical level the explorative research project indicates that the performance of an innovation leadership style can have a positive effect on the ecological innovativeness of a construction project when the leading manager also assures that the project is injected with information, knowledge and competence in the field of ecology and ecological building. It also indicates that a manager's consistent performance of a leadership style, without an effort to eliminate the information, knowledge and competence deficiency of the construction project, has no positive effect on the ecological innovativeness of the project. 


\section{Conclusion}

According to the leadership role model in the innovation management literature managers perform charismatic, instrumental, strategic, and interactive leadership styles to stimulate the innovative output of organizations. To explore the effectiveness of the four leadership styles in innovative construction projects, four comparable construction projects with the aim to innovate in the field of ecology were observed, described and analysed.

On an analytical level the case study explorations indicate that:

1) a manager's consistent performance of a leadership style, with an effort of the manager to eliminate the ecological information, knowledge and competence deficiency of the construction project, has a positive effect on the ecological innovativeness of the project.

2) a manager's consistent performance of a leadership style, without an effort of the manager to eliminate the ecological information, knowledge and competence deficiency of the construction project, has no positive effect on the ecological innovativeness of the project.

Although the research project is designed to explore the effect of leadership styles on the innovativeness of ecological construction projects, and not to focus on the role of ecological information, knowledge and competence, the empirical findings indicate that this role is crucial. Further research to explore the effectiveness of innovation leadership styles on the innovativeness of construction projects should integrate the role of information, knowledge and competence in the theoretical framework, and in the description and analysis of the empirical research findings. 


\section{References}

Bailetti, A., Callahan, J., McClusky, S., 1998, Coordination at different stages of the product design process, $R \& D$ Management, 28(4), 237-247.

Barczak, G., Wilemon, D., 1989, Leadership differences in new product development teams, Journal of Product Innovation Management, 6(4), 259-267.

Bass, B.M., 1985, Leadership And Performance Beyond Expectations, New York: The Free Press, pp. 256.

Bass, B.M., 1990, From transactional to transformational leadership: learning to share the vision, Organizational Dynamics, 18(3), 19-36.

Blake, R., Mouton, J.S., 1985, The Managerial Grid, Houston: Gulf, pp. 244.

Bossink, B.A.G., 2004, Managing drivers of innovation in construction networks, Journal of Construction Engineering and Management, 130(3), 337-345.

Bossink, B.A.G., 2002a, A Dutch public-private strategy for innovation in sustainable construction, Construction Management and Economics, 20(7), 633-642.

Bossink, B.A.G., 2002b, Innovative quality management practices in the Dutch 
construction industry, International Journal of Quality and Reliability Management, 19(2), 170-186.

Bossink, B.A.G., 2002c, The development of co-innovation strategies: stages and interaction patterns in interfirm innovation, $R \& D$ Management, 32(4), 311-320.

Bossink, B.A.G., 2002d, The strategic function of quality in the management of innovation, Total Quality Management, 13(2), 195-205.

Burns, J.M, 1978, Leadership, New York: Harper \& Row, pp. 531.

Burpitt, W.J., Bigoness, W.J., 1997, Leadership and innovations among teams: the impact of empowerment, Small Group Research, 28(3), 414-423.

Bycio, P., Allen, J.S., Hackett, R.D., 1995, Further assessment of Bass's (1985) conceptualization of transactional and transformational leadership, Journal of Applied Psychology, 80(4), 468-478.

Chakrabarti, A.K., 1974, The role of champion in product innovation, California Management Review, 17(2), 58-62.

Clark, K.B., Wheelwright, S.C., 1992, Organizing and leading "heavyweight" development teams, California Management Review, 34(3), 9-28. 
Creswell, J.W., 2003, Research Design; Qualitative, Quantitative, and Mixed Methods Approaches, Sage: Thousand Oaks, pp. 246.

Cunningham, J.B., 1997, Case study principles for different types of cases, Quality and Quantity, 31(4), 401-423.

Daft, R.L., 1999, Leadership; Theory and Practice, Fort Worth: The Dryden Press, pp. 496.

Eisenbach, R., Watson, K., Pillai, R., 1999, Transformational leadership in the context of organizational change, Journal of Organizational Change, 12(2), 80-88.

Eisenhardt, K.M., 2002, Building theories from case study research. In: Huberman, A.M., Miles, M.B. (ed.) The Qualitative Researcher's Companion, Sage: Thousand Oaks, 5-35.

Evans, M.G., 1970, The effects of supervisory behaviour on the path-goal relationship, Organizational Behaviour and Human Performance, 5(3), 277-298.

Fiedler, F.E., 1967, A Theory of Leadership Effectiveness, New York: McGraw-Hill, pp. 310. 
Galbraith, J.R., 1982, Designing the innovating organization, Organizational Dynamics, 10(3), 5-25.

Gann, D.M., 2000, Building Innovation; Complex Constructs in a Changing World, Thomas Telford: London, pp. 257.

Gardner, H., 1995, Leading Minds: An Anatomy of Leadership, New York: Basic Books, pp. 400.

Halbesleben, J.R.B., Novicevic, M.M., Harvey, M.G., Buckley, M.R., 2003, Awareness of temporal complexity and innovation: a competency-based model, The Leadership Quarterly, 14(4-5), 433-454.

Harmsen, H., Grunert, K.G., Declerck, F., 2000, Why did we make that cheese? An empirically based framework for understanding what drives innovation activity, $R \& D$ Management, 30(2), 151-166.

Hauschildt, J., Kirchmann, E., 2001, Teamwork for innovation - the troika of promotors. R\&D Management, 31(1), 41-49.

Hemphill, J.K., Coons, A.E., 1957, Development of the leader behaviour description questionnaire, in Leader Behaviour: its Description and Management, Stogdill, R.M., Coons, A.E. (eds) Columbus: Ohio State University, pp. 168. 
Hersey, P., Blanchard, K.H., 1982, Management of Organizational Behaviour: Utilizing Human Resources, Englewood-Cliffs: Prentice-Hall, pp. 345.

Howell, J.M., Avolio, B.J., 1993, Transformational leadership, transactional leadership, locus of control, and support for innovation: key predictors of consolidated-business-unit performance, Journal of Applied Psychology, 78(6), 891-902.

Howell, J.M., Higgins, C.A., 1990, Champions of technological innovation, Administrative Science Quarterly, 35(2), 317-341.

Jung, D.I., Chow, C., Wu, A., 2003, The role of transformational leadership in enhancing organizational innovation: hypothesis and some preliminary findings, The Leadership Quarterly, 14(4-5), 525-544.

Kerr, S., Jermier, J.M., 1978, Substitutes for leadership: their meaning and measurement, Organizational Behaviour and Human Performance, 22(3), 375-403.

Kim, Y., Min, B., Cha, J., 1999, The roles of R\&D team leaders in Korea: a contingent approach, $R \& D$ Management, 29(2), 153-166.

Kirkpatrick, S.A., Locke, E.A., 1991, Leadership: do traits matter? Academy of Management Executive, 5(2), 48-60. 
Koh, W.L., Steers, R.M., Terborg, J.R., 1995, The effects of transformational leadership on teacher attitudes and student performance in Singapore, Journal of Organizational Behaviour, 16(4), 319-333.

Lawless, M.W., Price, L.L., 1992, An agency perspective on new technology champions, Organization Science, 3(3), 342-355.

Lewin, K., 1939, Field theory and experiment in social psychology: concepts and methods, American Journal of Sociology, 44(6), 868-896.

Likert, R., 1979, From production- and employee-centredness to systems, Journal of Management, 5, 147-156.

Maidique, M.A., 1980, Entrepreneurs, champions, and technological innovation, Sloan Management Review, 21(2), 59-76.

Markham, S.K., 1998, A longitudinal examination of how champions influence others to support their projects. Journal of Product Innovation Management, 15(6), 490-504.

McDonough, E.F., Leifer, R.P., 1986, Effective control of new product projects: the interaction of organization culture and project leadership, Journal of Product Innovation Management, 3(3), 149-157. 
McDonough, E.F., Barczak, G., 1991, Speeding up new product development: the effects of leadership style and source of technology, Journal of Product Innovation Management, 8(3), 203-211.

Nadler, D.A., Tushman, M.L., 1990, Beyond the charismatic leader: leadership and organizational change, California Management Review, 32(2), 77-97.

Nam, C.H., Tatum, C.B., 1989, Toward understanding of product innovation process in construction, Journal of Construction Engineering and Management, 115(4), 517-534.

Nam, C.H., Tatum, C.B., 1997, Leaders and champions for construction innovation, Construction Management and Economics, 15(4), 259-270.

Nonaka, I., Kenney, M., 1991, Towards a new theory of innovation management: a case study comparing Canon Inc. and Apple Computer Inc, International Journal of Engineering and Technology Management, 8, 67-83.

Norrgren F., Schaller, J., 1999, Leadership style: its impact on cross-functional product development, Journal of Product Innovation Management, 16(4), 377-384.

Quinn, J.B., 1979, Technological innovation, entrepreneurship, and strategy, Sloan Management Review, 20(3), 19-30. 
Rice, M.P., O'Connor, G.C., Peters, L.S., Morone, J.G., 1998, Managing discontinuous innovation, Research-Technology Management, 41(3), 52-58.

Roberts, E.B., Fusfeld, A.R., 1981, Staffing the innovative technology-based organization, Sloan Management Review, 22(3), 19-34.

Saleh, S.D., Wang, C.K., 1993, The management of innovation: strategy, structure, and organizational climate, IEEE Transactions on Engineering Management, 40(1), 14-21.

Schumpeter, J.A., 1934, The Theory of Economic Development; An Inquiry Into Profits, Capital, Credit, Interest, and the Business Cycle, Cambridge: Harvard University press, pp. 255.

Shane, S.A., Venkataraman, S., MacMillan, I.C., 1994, The effects of cultural differences on new technology championing behaviour within firms, The Journal of High Technology Management Research, 5(2), 163-181.

Sillince, J.A.A., 1994, A management strategy for innovation and organizational design: the case of MRP2/JIT production management systems, Behaviour \& Information Technology, 13(3), 216-227. 
Stogdill, R.M., 1948, Personal factors associated with leadership: a survey of the literature, Journal of Psychology, 25, 35-71.

Stoker, J.I., Looise, J.C., Fisscher, O.A.M., De Jong, R.D., 2001, Leadership and innovation: relations between leadership, individual characteristics and the functioning of R\&D teams, International Journal of Human Resource Management, 12(7), 1141-1151.

Tatum, C.B., 1989, Organizing to increase innovation in construction firms, Journal of Construction Engineering and Management, 115(4), 602-617.

Vroom, V.H., Jago, A.G., 1988, The New Leadership: Managing Participation in Organizations, Englewood-Cliffs: Prentice-Hall, pp. 244.

Waters, J., 2000, Achieving innovation or the holy grail: managing knowledge or managing commitment? International Journal of Technology Management, 20(5-8), 819838.

Winch, G., 1998, Zephyrs of creative destruction: understanding the management of innovation in construction, Building Research \& Information, 26(4), 268-279.

Yin, R.K., 2003, Case Study Research; Design and Methods, Sage: Thousand Oaks, pp. 181. 